\title{
Untangling the confusion around land carbon science and climate change mitigation policy
}

\author{
Brendan Mackey ${ }^{1 \star}$, I. Colin Prentice ${ }^{2,3}$, Will Steffen ${ }^{4}$, Joanna I. House ${ }^{5}$, David Lindenmayer ${ }^{4}$, \\ Heather Keith ${ }^{4}$ and Sandra Berry ${ }^{4}$
}

Depletion of ecosystem carbon stocks is a significant source of atmospheric $\mathrm{CO}_{2}$ and reducing land-based emissions and maintaining land carbon stocks contributes to climate change mitigation. We summarize current understanding about human perturbation of the global carbon cycle, examine three scientific issues and consider implications for the interpretation of international climate change policy decisions, concluding that considering carbon storage on land as a means to 'offset' $\mathrm{CO}_{2}$ emissions from burning fossil fuels (an idea with wide currency) is scientifically flawed. The capacity of terrestrial ecosystems to store carbon is finite and the current sequestration potential primarily reflects depletion due to past land use. Avoiding emissions from land carbon stocks and refilling depleted stocks reduces atmospheric $\mathrm{CO}_{2}$ concentration, but the maximum amount of this reduction is equivalent to only a small fraction of potential fossil fuel emissions.

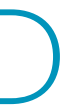
espite the current level of mitigation effort, global $\mathrm{CO}_{2}$ emissions continue to increase ${ }^{1}$. In addition to reducing emissions from fossil-fuel burning, the largest $\mathrm{CO}_{2}$ source globally, mitigation efforts now include reducing what is in aggregate the second largest net source of $\mathrm{CO}_{2}$ to the atmosphere: namely, carbon emissions from land-use change. Land carbon emissions accounted for about $36 \%$ of the anthropogenic $\mathrm{CO}_{2}$ emitted into the atmosphere from $1850-2000^{2}$, and about $12 \%$ of annual global $\mathrm{CO}_{2}$ emissions from 2000 to $2010^{1}$. Avoiding and reducing land carbon emissions is therefore an integral part of any comprehensive approach to solving the climate change problem.

Globally, forests store around $300 \mathrm{Pg} \mathrm{C}$ (reported range 240-500 $\mathrm{Pg} \mathrm{C}$ ) in living biomass ${ }^{2,3}$, equivalent to $\sim 140 \mathrm{ppm}$ of atmospheric $\mathrm{CO}_{2}$ (atmCO $\mathrm{CO}_{2}$; used to denote the concentration of $\mathrm{CO}_{2}$ in the atmosphere, and although the SI unit for atmCO is $\mu \mathrm{mol} \mathrm{mol}{ }^{-1}$, we have adopted the more familiar unit of ppm). Forests are distributed in both developed and developing countries (Table 1). About half of the world's forests have already been cleared, with 40 million $\mathrm{km}^{2}$ remaining and around 0.16 million $\mathrm{km}^{2}$ of forest cleared annually ${ }^{3}$. Only $36 \%\left(\sim 14.4\right.$ million $\left.\mathrm{km}^{2}\right)$ of the world's forest is now primary forest $^{3}$. In addition to deforestation, forests have been degraded by land-use activities such as logging and soil disturbance that deplete their organic carbon stocks and emit $\mathrm{CO}_{2}$. Emissions from forest degradation are poorly quantified globally, but estimates indicate that they increase regional carbon emissions by nearly $50 \%$ over deforestation alone $e^{4}$. Conserving the world's remaining primary forests would avoid substantial emissions of $\mathrm{CO}_{2}$. Afforestation and reforestation, moreover, can directly remove $\mathrm{CO}_{2}$ from the atmosphere - but only up to a point, as we discuss later.

Nations are engaged in negotiations to reduce emissions of $\mathrm{CO}_{2}$ and other greenhouse gases (GHGs) under the United Nations Framework Convention on Climate Change (UNFCCC). Developed countries that are signatories to the Kyoto Protocol (ratified by 37 countries and the European Union) committed themselves to a target of reducing their emissions of GHGs from 2008-2012, relative to
1990 levels. The target reduction was based on emissions from fossil fuels and industry, but removals by the land sector could be counted towards meeting the target. The Clean Development Mechanism under the Kyoto Protocol allowed for developed countries to offset fossil fuel emissions through, among other things, planting trees in developing countries. Similar kinds of offset project are allowed through the Joint Implementation mechanisms between developed countries. The extension or successor to the Kyoto Protocol is now being negotiated. There are parallel negotiations underway on the development of policies for Reducing Emissions from Deforestation and Degradation (REDD) - a voluntary scheme to mitigate land carbon emissions from developing countries.

Negotiated policy decisions involve political compromises to accommodate national interests. So far these decisions have fallen short of what will be necessary if atmCO $\mathrm{CO}_{2}$ is to be stabilized at a level that avoids major climate change ${ }^{5}$. Furthermore, there is the potential for perverse outcomes whereby mitigation efforts not only fail to reduce atmCO $\mathrm{CO}_{2}$, but even have negative impacts - either causing atm $\mathrm{CO}_{2}$ to increase or adversely affecting other landscape values, such as biodiversity. Perverse outcomes can result from a gap between land carbon policy decisions and scientific understanding of what is required for successful mitigation: that is, from confusion around land carbon science.

In this Perspective we clarify some well-established fundamentals of the global carbon cycle that are frequently either misunderstood, or seemingly overlooked. This information provides the scientific context for considering the potential of land-based mitigation and to what extent it can be legitimately considered an 'offset' for fossil fuel $\mathrm{CO}_{2}$ emissions. We do not advocate any particular policy, but we do draw attention to some proposed approaches that are likely to be ineffective, or worse.

\section{Human perturbation of the global carbon cycle}

The global carbon cycle is the subject of considerable confusion among non-specialists. A clear understanding of how humans have

${ }^{1}$ Griffith Climate Change Response Program, Griffith University, Gold Coast City, Parklands Drive, Southport, Queensland 4222, Australia, ${ }^{2}$ Macquarie University, Balaclava Road, North Ryde, New South Wales 2109, Australia, ${ }^{3}$ Grantham Institute for Climate Change and Division of Ecology and Evolution, Imperial College, Silwood Park, Ascot SL5 7PY, UK, ${ }^{4}$ The Fenner School of Environment and Society, The Australian National University, Canberra, Australian Capital Territory 0200, Australia, ${ }^{5}$ Bristol University, University Road, Clifton, Bristol BS8 1SS, UK. *e-mail: b.mackey@griffith.edu.au 
perturbed the cycle's natural stocks and flows of carbon is essential background to clarifying key scientific issues and ensuring effective policies.

Figure 1 illustrates changes in the primary stocks of the global carbon cycle as the result of human activity in three stylized time periods: the pre-agricultural era $(>8000 \mathrm{yr}$ BP; Fig. 1a); the preindustrial era (8 $000 \mathrm{yr}$ вP-1850, Fig. 1b); and the contemporary era (>1850-present day; Fig. 1c). These correspond with major phase shifts in the magnitude of the human environmental footprint in terms of land clearing and use of fossil fuels. Figure 1a shows that in the pre-agricultural era there was no human use of fossil fuel and relatively minimal depletion of land carbon due to human land use. Figure $1 \mathrm{~b}$ and $1 \mathrm{c}$ show the impact of human activity on the primary stocks. The sources and calculations for the values in Fig. 1 are provided in Table 2.

During the pre-industrial era, land carbon began to be depleted (white segment of land carbon stocks) leading to an increase in the atmospheric carbon stock, with some of this carbon dissolving into the ocean stock (as indicated by the green segments). In the contemporary era humans began mining fossil fuel and burning it as a source of energy, as well as engaging in accelerated land clearance. Both activities have resulted in $\mathrm{CO}_{2}$ emissions and a rapid and significant increase in the atmospheric carbon stock. A portion of the anthropogenic emissions added to the atmosphere is concurrently taken up by plants, and a fraction is dissolved into the ocean stock. This effect is illustrated in Fig. 1c by the segments of black carbon in the land and ocean stocks.

Figure 1d illustrates the hypothetical case of cleared land being largely returned to its pre-agricultural carbon stock levels. The amount of atmospheric carbon that potentially can be stored in the land buffer is, to first order, limited to the amount of carbon that was depleted from previous land use. The black segment signifies that an extra, modest amount of fossil fuel emissions could be stored as the result of the so-called $\mathrm{CO}_{2}$ fertilization effect discussed below.

\section{The lifetime of $\mathrm{CO}_{2}$ in the atmosphere}

A recurrent, serious misunderstanding is that the residence time in the atmosphere of a unit of $\mathrm{CO}_{2}$ emitted from fossil fuel burning is quite short, on the order of a century. The First Assessment Report ${ }^{6}$ of the Intergovernmental Panel on Climate Change (IPCC) incorrectly stated the 'lifetime' of $\mathrm{CO}_{2}$ to be $\sim 120$ years. Many commentators since have assumed it to be about 100 years. They have probably been encouraged in this view by the use of a 100-year timeframe for the calculation of 'global warming potentials' (GWP, expressed relative to $\mathrm{CO}_{2}$ ) for greenhouse gases with different lifetimes. However, it has long been recognized that any single number for the $\mathrm{CO}_{2}$ lifetime conceals more than it reveals. $\mathrm{CO}_{2}$ is taken up from the atmosphere by several distinct processes that have hugely different time constants ${ }^{7,8}$. Part of it is taken up by the land, and part dissolves in the ocean surface and mixes to the deep ocean. About $60 \%$ is removed from the atmosphere on a time scale of 100 years but it takes a very long time to remove the remaining fraction. A 'pulse' or unit of $\mathrm{CO}_{2}$ emitted to the atmosphere is only fully removed from the atmosphere so that it no longer interacts with the climate system when it has completely dissolved in the deep ocean - a process requiring the concurrent dissolution of carbonate from ocean sediments (about 5,000 to 10,000 years) and enhanced weathering of silicate rocks (around 100,000 years). Modelling by Archer and colleagues indicated that $20-35 \%$ of the $\mathrm{CO}_{2}$ emitted will still be in the atmosphere after 2-20 millennia. Tracing the history of the misunderstanding of $\mathrm{CO}_{2}$ lifetimes, they commented that "...the result has been an erroneous conclusion, throughout much of the popular treatment of the issue of climate change, that global warming will be a century-timescale phenomenon"9.

The reality is that for all practical purposes, fossil fuel $\mathrm{CO}_{2}$ emission is irreversible ${ }^{10}$. Any eventual stable at $\mathrm{CO}_{2}$ will be dictated
Table 1 | Top 10 countries for total area of forest and other wooded land (see Annex Table 3, ref. 3).

\begin{tabular}{lllll} 
Rank & Country & Forest (1,000ha) & Country & $\begin{array}{l}\text { Other wooded } \\
\text { land (1,000ha) }\end{array}$ \\
\hline 1 & $\begin{array}{l}\text { Russian } \\
\text { Federation }\end{array}$ & 809,090 & Australia & 135,367 \\
2 & Brazil & 519,522 & China & 102,012 \\
3 & Canada & 310,134 & Canada & 91,951 \\
4 & USA & 304,022 & Russian & 73,220 \\
& & & Federation & \\
5 & China & 206,861 & Argentina & 61,471 \\
6 & DRC & 154,135 & Sudan & 50,224 \\
7 & Australia & 149,300 & Ethiopia & 44,650 \\
8 & Indonesia & 94,432 & Brazil & 43,772 \\
9 & Sudan & 69,949 & Botswana & 34,791 \\
10 & India & 68,434 & Afghanistan & 29,471
\end{tabular}

by total accumulated emissions over the preceding centuries ${ }^{11}$ and not by the contemporaneous balance of emissions and removals. In this respect $\mathrm{CO}_{2}$ behaves quite differently from the other major so-called long-lived GHGs - methane and nitrous oxide - which have atmospheric lifetimes in the order of 10 years and 100 years, respectively. This difference implies an important caveat for the use of GWP. Reduced emissions of nitrous oxide or methane might be substituted for reduced emissions of an 'equivalent' amount of $\mathrm{CO}_{2}$. But the effects of the emitted $\mathrm{CO}_{2}$ will continue to be felt for thousands of years, long after the effects of the reduced emissions of the other gases have disappeared.

\section{The limited capacity of land carbon stocks}

Land carbon plays an important role in the stocks and flows of the global carbon cycle, but the magnitude is limited and it has particular characteristics which contrast with the different qualities of the other main categories of carbon stocks (fossil fuel, atmosphere and ocean). The fossil fuel carbon stock was built up very slowly over millions of years and does not de-gas into the atmosphere at any significant rate. Emissions from this stock in the contemporary era constitute a one-way flow, which is a direct result of human activity. Carbon is stored in the other three major categories of stocks in different forms (on land as biomass and soil organic carbon, in the atmosphere as $\mathrm{CO}_{2}$ gas and in the ocean primarily as dissolved inorganic carbon) and both the land and ocean carbon stocks naturally exchange with the atmospheric stock.

The potential size of the land carbon stock is determined chiefly by climate, and modified locally by substrate and topography, and the effects these have on plant growth ${ }^{12}$. The capacity of the land to remove atmospheric carbon and store it in vegetation and soil is limited to the amount previously depleted by land use. It has been estimated that if all the carbon so far released by land-use changes (mainly deforestation) could be restored through reforestation this would reduce atmCO $\mathrm{CO}_{2}$ at the end of the century by $40-70 \mathrm{ppm}$. Conversely, complete global deforestation over the same time frame would increase atmospheric concentrations by about $130-290 \mathrm{ppm}^{13}$. In comparison, the projected range of atmCO $\mathrm{CO}_{2}$ in 2100 , under a range of fossil fuel emissions scenarios developed for the IPCC, is $170-600 \mathrm{ppm}$ above 2000 levels $^{14}$.These estimates highlight the very modest scope for reforestation to reduce atmCO compared with both the magnitude of fossil fuel $\mathrm{CO}_{2}$ emissions and emissions from derorestation and degradation. Moreover, complete reforestation of previously cleared land is an implausible scenario due to competing land uses - especially from food production 
a

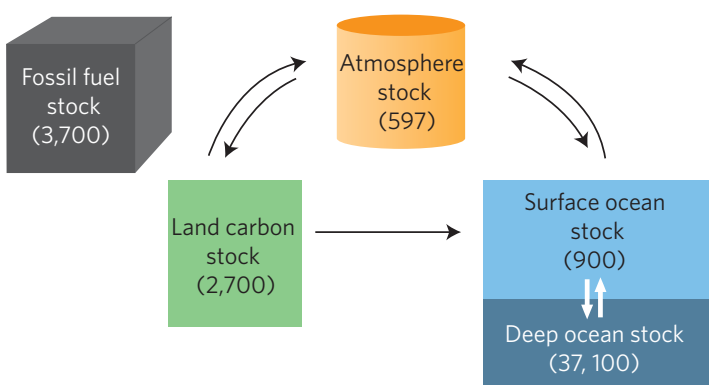

c

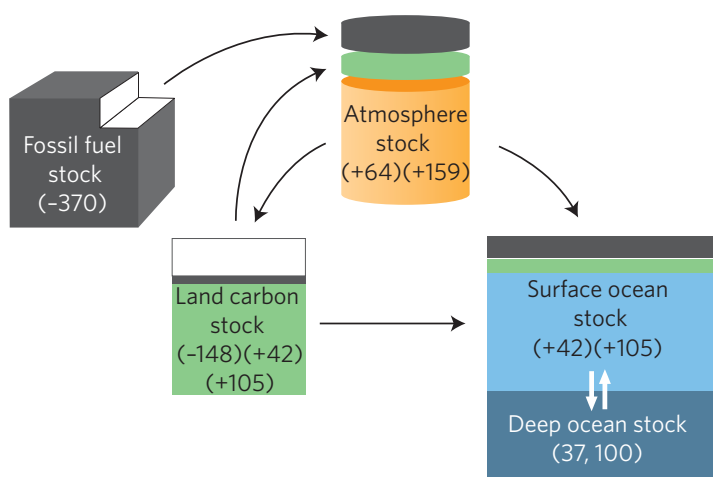

b

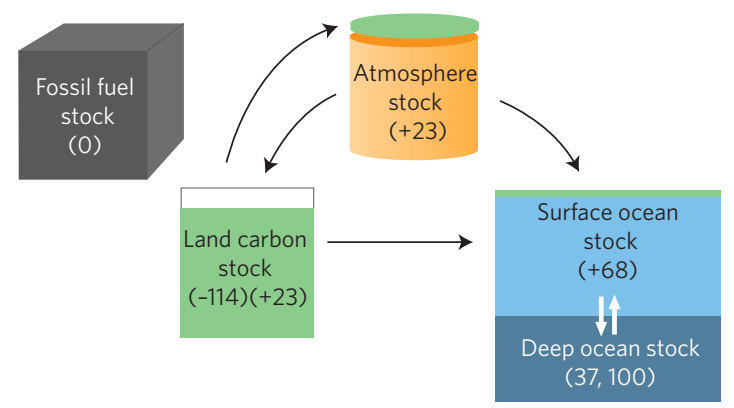

d
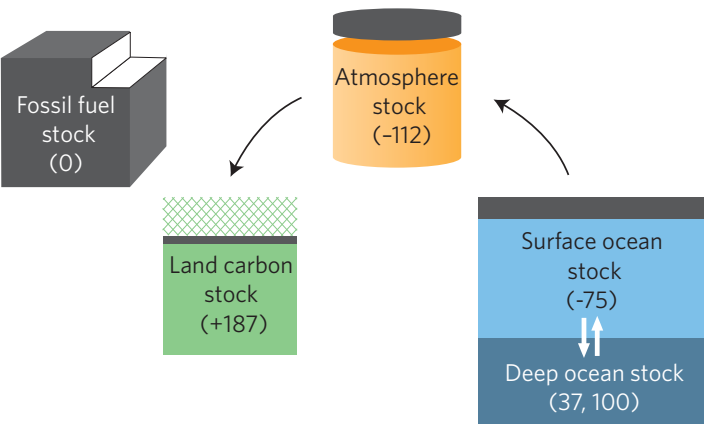

Figure 1 | Changes in the primary stocks of the global carbon cycle. a-c, A stylized illustration of the impact of human activity on the primary stocks over three time periods: the pre-agricultural era (>8,000 yr BP; a); pre-industrial era ( 8,000 yr BP to 1850; b); and contemporary era (1850 to the present day; c). The objects (cylinders and rectangles) represent the primary stocks of carbon in the major reservoirs of the global carbon cycle (fossil fuel, atmosphere, land, surface ocean and deep ocean) but are not drawn to scale. d, The hypothetical and unachievable case of "refilling" the land stock, that is, if all previously cleared land being returned to its pre-agricultural carbon stock with zero continuing fossil fuel emissions. Numbers in parentheses $(\mathrm{Pg} \mathrm{C})$ are indicative estimates of the carbon stocks (a) and changes in carbon stocks (b-d). The arrows represent the direction of carbon flows (fluxes) between stocks over the era, with arrows in panel a representing the natural background carbon cycle, and arrows in the other panels indicating the impact of anthropogenic change. Natural processes (as shown in panel a) involve two-way exchanges of carbon between the atmosphere-ocean (on the order of $70 \mathrm{Pg}\left(\mathrm{yr}^{-1}\right.$ ) and atmosphere-land (around $120 \mathrm{Pg} \mathrm{C} \mathrm{yr}^{-1}$ ) with a small natural hydrological flux of carbon discharged from rivers into oceans of $0.8 \mathrm{Pg} C \mathrm{yr}^{-1}$ (not shown are the very small sources due to volcanic activity and sinks due to weathering) ${ }^{42}$. The anthropogenic changes due to land use change and burning fossil fuels are also illustrated using colour coded slices (also not drawn to scale). These changes reflect processes that can be considered in general terms as operating over two timescales: on the order of a one to a few 1,000 years about $20 \%$ of the emitted $\mathrm{CO}_{2}$ stays in the atmosphere ${ }^{44,9}, 60 \%$ is taken up by the ocean and $20 \%$ by land 44 ; on the time scale of 100 years $43 \%$ of emissions remain in the atmosphere ${ }^{45,46}$ with the rest taken up roughly equally between the land and ocean ${ }^{46}$. We use the simplified assumption that as atmospheric $\mathrm{CO}_{2}$ is reduced, the ocean would 'outgas' $\mathrm{CO}_{2}$, and the land would also outgas the carbon uptake due to the $\mathrm{CO}_{2}$ fertilization effect, based on processes operating over the 100-yr timescale. The land retains the $\mathrm{C}$ uptake from fossil fuel emissions. Even if the unachievable was accomplished, after 100 years, there would still be an extra 134 Pg $C$ in the atmosphere compared with the pre-agricultural era due to fossil fuel emissions. The estimates are based on sources and calculations in Table 2.

and the need to feed a human population predicted to surpass nine billion by $2050^{15}$ - along with projected demand for land to produce transport biofuel of $0.3-0.5$ million $\mathrm{km}^{2}$ by $2030^{16}$. And even under this impossible scenario, land degradation means that some of the land carbon stock cannot be re-filled.

\section{The difference between stocks and sinks}

Land carbon scientists are clear on the difference between land carbon stocks and sinks, however policymakers and the interested citizen can be excused for not understanding (or sometimes forgetting) the distinction. As used in carbon cycle science, the term 'sink' always implies a net removal of carbon from the atmosphere in other words, a net flux of carbon into the ecosystem. There is a persistent risk of confusion between a stock (in units of mass, $\mathrm{g} \mathrm{C}$ )

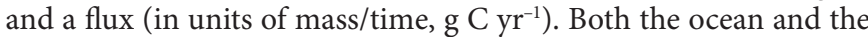

land are indeed taking up part of the $\mathrm{CO}_{2}$ that is emitted by human activities, so they do constitute sinks. But this uptake is a transient effect as discussed below.

The land carbon stock can be described as a 'buffer' by analogy with the term used in computer science to describe a device which temporarily stores data. The impact of land use activity is appropriately reported or accounted for as a change in stock over a given time period, that is, a depletion or re-filling of the buffer. When a forest is re-planted, at first it functions as a sink - with the net uptake of $\mathrm{CO}_{2}$ due to photosynthesis being greater than respiration - and carbon is accumulating in woody biomass and soil. Over time, the net sink rate declines as the growth rate decreases relative to respiration rates. If the forest is allowed to develop into an ecologically mature state, the carbon stock approaches a dynamic equilibrium with prevailing environmental conditions, where 


\section{Table 2 | The sources and calculations for estimated changes of carbon stocks in Fig. 1}

\section{(a) Pre-agricultural}

\begin{tabular}{lll}
\hline Stock & Pg C & Sources and calculations (references given in parentheses) \\
Fossil fuel & 3,700 & Fig. 7.3 (42) \\
Land & 2,700 & Fig. 7.3(42) \\
Atmosphere & 597 & Fig. 7.3(42) \\
Shallow ocean & 900 & Fig. 7.3 (42) \\
Deep ocean & 37,100 & Fig. 7.3 (42) \\
(b) Pre-industrial (change from pre-agricultural) &
\end{tabular}

(b) Pre-industrial (change from pre-agricultural)

\begin{tabular}{|c|c|c|}
\hline Fossil fuel & 0 & \\
\hline Land & $\begin{array}{l}-114 \\
23\end{array}$ & $\begin{array}{l}\text { Emissions from land clearance (43) } \\
20 \% \text { taken up by land due to } \mathrm{CO}_{2} \text { fertilization effect, 1,000-year timescale (44) }\end{array}$ \\
\hline Atmosphere & 23 & $20 \%$ of emissions remain in atmosphere, 1,000 -year timescale $(9,44)$ \\
\hline Ocean & 68 & $60 \%$ taken up by ocean, 1,000-year timescale (44) \\
\hline \multicolumn{3}{|c|}{ (c) Contemporary (change from pre-industrial) } \\
\hline Fossil fuel & -370 & IPCC Fossil fuel emissions (42) \\
\hline Land & $\begin{array}{l}-148 \\
42 \\
105\end{array}$ & $\begin{array}{l}\text { Emissions from land clearance (43) } \\
28.5 \% \text { of land carbon emissions taken up by land due to } \mathrm{CO}_{2} \text { fertilization effect, } 100 \text {-year timescale (46) } \\
28.5 \% \text { of land carbon emissions taken up by land due to } \mathrm{CO}_{2} \text { fertilization effect, } 100 \text {-year timescale (46) }\end{array}$ \\
\hline Atmosphere & $\begin{array}{l}64 \\
159\end{array}$ & $\begin{array}{l}43 \% \text { of land carbon emissions remain in atmosphere } 100 \text {-year timescale }(45,46) \\
43 \% \text { of fossil fuel carbon emissions remain in atmosphere } 100 \text {-year timescale }(45,46)\end{array}$ \\
\hline Ocean & $\begin{array}{l}42 \\
105\end{array}$ & $\begin{array}{l}28.5 \% \text { of land carbon emissions taken up by ocean, } 100 \text {-year timescale (46) } \\
28.5 \% \text { of land carbon emissions taken up by ocean, } 100 \text {-year timescale (46) }\end{array}$ \\
\hline
\end{tabular}

(d) Hypothetical restoration of the land carbon buffer (change from contemporary)

\begin{tabular}{|c|c|c|}
\hline Fossil fuel & 0 & \\
\hline Land & 187 & $\begin{array}{l}+262 \text { restored to the land }(114+148) \text {, minus } 28.5 \% \text { reduced } \mathrm{CO}_{2} \text { fertilization effect }(-75) \text {, } 100 \text {-year } \\
\text { timescale }\end{array}$ \\
\hline Atmosphere & -112 & $\begin{array}{l}-262 \text { removed by land restoration, }+75 \text { out-gassed from ocean, }+75 \text { reduced } \mathrm{CO}_{2} \text { fertilization effect on } \\
\text { land }\end{array}$ \\
\hline Ocean & -75 & Response of ocean to lowered atmospheric $\mathrm{CO}_{2}$ is out-gassing of $28.5 \%$ of 262,100 -yr timescale \\
\hline
\end{tabular}

respiration approximately balances photosynthesis. At this point, the depleted land carbon stock has been refilled and the sink function has gone. The mitigation value of the ecosystem resides in maintenance of the stored carbon stock.

At present some forests have carbon sequestration potential due to depletion of carbon stocks from past land use ${ }^{17}$. Reforestation of previously cleared or logged land (especially in Europe, the USA and China), together with deforestation and degradation (especially, but not exclusively, in tropical developing countries), are all included in the calculation of net emissions noted above from land use change.

The land and ocean are sinks, and globally they removed an estimated $56 \%$ of all $\mathrm{CO}_{2}$ emitted from human activities during the period 1958-2010, each sink in roughly equal proportion ${ }^{18}$. Although land-use change is a source of emissions, the land as a whole is functioning as a sink at present. This land sink reflects the natural response of ecosystems to the influence of environmental change, which is now leading to a net uptake of $\mathrm{CO}_{2}$ due to several factors. Rising atmCO $\mathrm{C}_{2}$ leads to a boost in plant productivity (the $\mathrm{CO}_{2}$ fertilization effect), whereby the increase in net primary production outpaces the increase in respiration of soil carbon stocks ${ }^{19,20}$. Experimental evidence has shown that net primary productivity of temperate forests increases by around $23 \%$ in response to a $200 \mathrm{ppm}$ increase in $\mathrm{CO}_{2}$ (that is, when grown in atmCO $\left.\mathrm{CO}_{2} 550 \mathrm{ppm}\right)^{21}$. However, the effect varies geographically ${ }^{22}$, is constrained (to an uncertain degree) by nitrogen availability ${ }^{23}$ and depends on $\mathrm{CO}_{2}$ continuing to increase. If $\mathrm{CO}_{2}$ were stabilized, this effect would disappear probably after a lag of a few decades. The practical effect of an increase in atmospheric $\mathrm{CO}_{2}$ on potential ecosystem carbon stocks is a modest increase in the size of the buffer that could be refilled.
Ecologically mature ( $>200$ years) and old-growth forests aged up to 800 years can continue to function as sinks. Old-growth tropical forests accumulate around $5 \mathrm{Mg} \mathrm{C} \mathrm{km}^{-2} \mathrm{yr}^{-1}$ in living biomass, which could be yielding a carbon sink of $1.3 \mathrm{Pg} \mathrm{C} \mathrm{yr}^{-1}\left(0.8-1.6 \mathrm{Pg} \mathrm{C} \mathrm{yr}^{-1}\right)$ across all tropical forests ${ }^{24,25}$. We reiterate, however, that the mitigation value of tropical forests - and old-growth forests in general does not lie in their present, transient function as carbon sinks. In terms of carbon mitigation policy, the primary reason to conserve forests is the carbon stocks they contain. The idea that replacing primary forests by plantations will 'create sinks' and thereby be positive for climate mitigation is incorrect, as it fails to account for the loss of carbon stock from the primary forest ${ }^{26}$. Furthermore, plantation forests store less carbon than the pre-existing natural primary forest, secondary (regenerating) natural forests or a primary forest under the same environmental conditions ${ }^{27-30}$.

Climate change may increase potential carbon stocks in some regions: for example, through increased rainfall and/or decreased potential evaporation where plant growth is limited by water availability, and through enhancement of the growing season in northern temperate regions due to increases in temperature. But conversely, increasing aridity in other regions is likely to reduce plant growth through drying or heat stress ${ }^{31}$, and to increase the likelihood that forest areas are subject to wildfire, which can reduce the long-term carbon carrying capacity of landscapes ${ }^{32}$. Hence, there are competing processes resulting in changes in the potential land carbon stock. An analysis based on 13 coupled climate-carbon cycle models pointed to future climate change reducing the efficiency of the Earth system in absorbing anthropogenic carbon emissions, leading to a larger fraction of anthropogenic $\mathrm{CO}_{2}$ staying airborne 
and therefore some amplification of global warming. Despite large uncertainties, all models simulated a relative weakening of both the land and ocean carbon sinks in the future, warmer climate ${ }^{33}$.

\section{Policy implications}

UNFCCC negotiations are characterized by an extraordinary effort to make use of the best available science as reviewed by the IPCC. However, the negotiations are a complex political process with many interests operating, and as policies are implemented, scientific and/or unintended shortcomings in some decisions are revealed. These are inevitable given that the attempt to mitigate human-forced climate change is a new kind of problem. As inconsistencies in policies are revealed they should be seen as part of an ongoing process for scientists and negotiators to learn and make the necessary improvements.

Parties (that is, countries; including developed and developing) that are signatories to the UNFCCC report on emissions of $\mathrm{CO}_{2}$ due to change (depletion) in carbon stock from different land cover types. For this purpose they only report on areas of forests identified as 'managed' (but in practice these may include areas considered largely 'natural' - with native species and little or no timber removals, for instance). Under the Kyoto Protocol, Annex I (developed) countries account for changes in stock between the first commitment period (2008 to 2012) and 1990. Under Article 3.3, parties have to report all afforestation, reforestation and deforestation (that is, where there is a change of land use to or from forest land to another land class, such as grassland or cropland). Under Article 3.4 parties can elect to report changes in stocks on areas identified as 'Forest Management'; that is, it is not mandatory. Some countries, Australia for example, opted not to report on these emissions.

The implementation of the Kyoto Protocol for forests is problematic ${ }^{35}$ as it does not apply a distinction between natural forest ecosystems and plantations, nor between primary forest and seminatural forests logged for industrial wood production as there is technically no change in land cover ${ }^{36}$. As noted above, clear-felling of natural forest for even-aged natural regeneration or plantation ${ }^{37}$ results in depletion of the land buffer and significant $\mathrm{CO}_{2}$ emissions $^{38}$. If forest management is elected, these emissions will be captured as change in stock in managed forests between 1990 and the commitment period. If it is not elected, the interpretation of the rules is that the land remains forest land, and no deforestation is deemed to have occurred.

The Durban accounting rules negotiated in 2010 for the second commitment period of the Kyoto Protocol (2013 to 2020) are a significant improvement and address two key concerns ${ }^{39}$. Accounting for emissions from forest management will be mandatory. Accounting for conversion of natural forests to plantation forests will be required (although it is not yet clear if this will be reported under deforestation or forest management). Furthermore, Parties will have to report on how harvesting or forest disturbance that is followed by the re-establishment of a forest is distinguished from deforestation.

Although future accounting approaches thus represent an improvement, there remain concerns that need attention by governments when formulating national policies and programs, and among business and civil society in promoting voluntary and market-based mitigation schemes. If carbon is to be usefully stored (on land, in the ocean or in geological repositories), it must remain stored not just for 100 years, but for more than 10,000 years. This issue of 'permanence' is widely recognized in the UNFCCC negotiations, but not necessarily on the long timescales involved. Indeed it is accepted de facto in many policy contexts that it is sufficient to maintain stores for 100 years. For example, Article 87 of the Australian Government's Carbon Credits (Carbon Farming Initiative) Act 2011 defines the maximum potential relinquishment period for an eligible offsets project as 100 years (that is, the time period the person holding the carbon credit is responsible for the sequestered carbon stock) ${ }^{40}$.

Voluntary carbon offset markets in operation that are used by business including airlines, industrial and energy companies ${ }^{41}$ tend to have similar misconceptions of the science. It helps to have clarity about the meaning and intention of an 'offset'. It must be recognized that forest conservation can avoid or reduce future carbon emissions, but does not in any meaningful sense offset continuing emissions from other sources. It must also be recognized that the capacity of the land buffer to remove and store $\mathrm{CO}_{2}$ from the atmosphere is strictly limited. However vigorous the measures taken to increase land carbon stocks, their total potential for carbon storage is minuscule compared with the stock of fossil fuels that could yet be burnt.

\section{Conclusions}

On the basis of our review of key scientific issues related to the global carbon cycle, the following insights should be considered when climate change mitigation polices are being negotiated, regulatory frameworks formulated and programmes and projects implemented.

As long as the right kinds of land management responses are implemented, the land carbon buffer can provide a valuable, cost-effective, short-term service in helping to reduce atmCO $\mathrm{C}_{2}$, and slow the rate of anthropogenic climate change, bringing cobenefits for biodiversity and sustainable livelihoods, and giving us some time to develop a low carbon economy.

There are strict, environmentally determined limits on the maximum amount of carbon that can be restored to land carbon stocks, and good reasons why this maximum will not be achieved. Sequestering carbon into depleted ecosystem stocks removes $\mathrm{CO}_{2}$ from the atmosphere and is thus usefully considered as partially refilling the buffer that was depleted by human activities. Avoiding emissions by protecting high-carbon ecosystems from land-use change that depletes their carbon stocks is an important part of a comprehensive approach to greenhouse gas mitigation. The mitigation value of forests lies not in their present net uptake of $\mathrm{CO}_{2}$, but in the longevity of their accumulated carbon stocks.

Consistent with our understanding of the lifetime of the airborne fraction of a pulse of $\mathrm{CO}_{2}$, the most effective form of climate change mitigation is to avoid carbon emissions from all sources. This means that there is no option but to cut fossil fuel emissions deeply, and not to continue these emissions under the erroneous assumption that they can be offset in the long term by the uptake of $\mathrm{CO}_{2}$ in land systems.

Received 30 October 2012; accepted 17 December 2012; published online 29 May 2013

\section{References}

1. Friedlingstein, P. et al. Update on $\mathrm{CO}_{2}$ emissions. Nature Geosci. 3, 811-812 (2010).

2. Houghton, R. A. Balancing the global carbon budget. Annu. Rev. Earth Planet. Sci. 35, 313-347 (2007).

3. Global Forest Resources Assessment 2010: Main Report Forestry Paper 163 (FAO, 2010).

4. Asner, G. P. et al. High-resolution forest carbon stocks and emissions in the Amazon. Proc. Natl Acad. Sci. USA 107, 16739-16742 (2010).

5. Vieweg, M. et al. Climate Action Tracker Update, 3 September 2012 (Climate Action Tracker, 2012); available via http://go.nature.com/CXg1v1

6. Shine, K. P., Derwent, R. G., Wuebbles, D. J. \& Morcrette, J. J. in IPCC First Assessment Report 1990: Scientific Assessment of Climate Change (eds Houghton, J. T., Jenkins, G. J. \& Ephraums, J. J.) 45-68 (Cambridge Univ. Press, 1990).

7. Solomon, S., Plattnerb, G., Knuttic, R. \& Friedlingstein, P. Irreversible climate change due to carbon dioxide emissions. Proc. Natl Acad. Sci. USA 106, 1704-1709 (2009).

8. Archer, D. \& Brovkin, V. The millennial atmospheric lifetime of anthropogenic $\mathrm{CO}_{2}$. Climatic Change 90, 283-297 (2008) 
9. Archer, D. et al. Atmospheric lifetime of fossil fuel carbon dioxide. Annu. Rev. Earth Planet. Sci. 37, 117-34 (2009).

10. Matthews, H. D. \& Caldeira, K. Stabilizing climate requires near-zero emissions. Geophys. Res. Lett. 35, L04705 (2008).

11. Allen, M. R. et al. Warming caused by cumulative carbon emissions towards the trillionth tonne. Nature 458, 1163-1166 (2009).

12. Roxburgh S. H. et al. Organic carbon partitioning in soil and litter in subtropical woodlands and open forests: A case study from the Brigalow Belt, Queensland. Rangeland J. 28, 115-125 (2006).

13. House, J. I., Prentice, I. C. \& Le Quéré, C. Maximum impacts of future reforestation or deforestation on atmospheric $\mathrm{CO}_{2}$. Glob. Change Biol. 8, 1047-1052 (2002).

14. Prentice, I. C. et al. in IPCC Climate Change 2001: The Scientific Basis (eds Houghton, J. T. et al.) 183-238 (Cambridge Univ. Press, 1990).

15. World Population Prospects: The 2010 Revision, Highlights and Advance Table Working Paper No. ESA/P/WP.220 (United Nations, 2011).

16. World Energy Outlook 2006 (OECD/IEA, 2006).

17. Keith, H., Mackey, B. \& Lindenmayer, D. Re-evaluation of forest biomass carbon stocks and lessons from the world's most carbon-dense forests. Proc. Natl Acad. Sci. USA 106, 11635-11640 (2009).

18. Carbon budget 2010 (Global Carbon Project, 2011); available at http://www.globalcarbonproject.org/carbonbudget/12/hl-full.htm

19. Denman, K. L. \& Brasseur, G. in Climate Change 2007: The Physical Science Basis (eds Solomon, S. D. et al.) Ch. 7, 500-587 (Cambridge Univ. Press, 2007)

20. Friedlingstein, P., Dufresne, J. L., Cox, P. M. \& Rayner, P. How positive is the feedback between climate change and the carbon cycle? Tellus $B$ 55, 692-700 (2003)

21. Norby, R. J. et al. Forest response to elevated $\mathrm{CO}_{2}$ is conserved across a broad range of productivity. Proc. Natl Acad. Sci. USA 102, 18052-18056 (2005).

22. Hickler, T. et al. $\mathrm{CO}_{2}$ fertilization in temperate FACE experiments not representative of boreal and tropical forests. Glob. Change Biol. 14, 1531-1542 (2008)

23. Richard, J. et al. $\mathrm{CO}_{2}$ enhancement of forest productivity constrained by limited nitrogen availability. Proc. Natl Acad. Sci. USA 107, 19368-19373 (2010).

24. Luyssaert, S. et al. Old-growth forests as global carbon sinks. Nature 455, 213-215 (2008).

25. Lewis, S. L. et al. Increasing carbon storage in intact African tropical forests. Nature 457, 1003-1006 (2009).

26. Dean, C., Wardell-Johnson, G. \& Kirkpatrick, J. B. Are there any circumstances in which logging primary wet-eucalypt forest will not add to the global carbon burden? Agric. For. Meteorol. 161, 156-169 (2012).

27. Liao, C., Luo, Y., Fang, C. \& Li, B. Ecosystem carbon stock influenced by plantation practice: Implications for planting forests as a measure of climate change mitigation. PLoS ONE 5, e10867 (2010).

28. Danielsen, F. et al. Biofuel plantations on forested lands: Double jeopardy for biodiversity and climate. Conserv. Biol. 23, 348-358 (2009).

29. Kanowski, J. \& Catterall, C. P. Carbon stocks in above-ground biomass of monoculture plantations, mixed species plantations and environmental restoration plantings in north-east Australia. Ecol. Restor. Manag. 11, 119-126 (2011)

30. Thompson, I., Mackey, B., McNulty, S. \& Mosseler, A. Forest Resilience, Biodiversity, and Climate Change. A Synthesis of the Biodiversity/Resilience/ Stability Relationship in Forest Ecosystems Technical Series No. 43 (Secretariat of the Convention on Biological Diversity, 2009).
31. Bates, B. C., Kundzewicz, Z. W., Wu, S. \& Palutikof, J. P. (eds) IPCC: Climate Change and Water (IPCC Secretariat, 2008)

32. Scholze, M., Knorr, W., Arnell, N. W. \& Prentice, I. C. A climate-change risk analysis for world ecosystems Proc. Natl Acad. Sci. USA 35, 13116-13120 (2006)

33. Friedlingstein, P. et al. Climate-carbon cycle feedback analysis: Results from the C4MIP model intercomparison. J. Climate 19, 3337-3353 (2006).

34. Report of the Conference of the Parties on its seventh session, held at Marrakesh from 29 October to 10 November 2000. Addendum Part Two: Action taken by the Conference of the Parties Volume I Annex C, Article 3, Paragraph 459 (UNFCCC 2000); available via http://go.nature.com/mmdUno

35. Neeff, T., Heiner von Luepke, H. V. \& Schoene, D. Choosing a Forest Definition for the Clean Development Mechanism Forests and Climate Change Working Paper 4 (FAO, 2006); available via http://go.nature.com/Kl6NQh

36. Sasaki, N. \& Putz, F. E. Critical need for new definitions of "forest" and "forest degradation" in global climate change agreements. Conserv. Lett. 2, 226-232 (2009).

37. Sustainable Forest Management Appendix 2: Data Tables (Forestry Tasmania, 2012); available via http://go.nature.com/2ymgMY

38. Harmon, M. E., Ferrell, W. K. \& Franklin, J. F. Effects of carbon storage of conversion of old-growth forests to young forests. Science 247, 699-702 (1990).

39. Report of the Conference of the Parties Serving as the Meeting of the Parties to the Kyoto Protocol on its Seventh Session, Held in Durban from 28 November to 11 December 2011 Addendum Part Two Annex A-E (UNFCCC, 2011); available via http://go.nature.com/A6gdR3

40. Carbon Credits (Carbon Farming Initiative) Act 2011 (Australian Government, 2011); available via http://go.nature.com/n1exIb

41. Coulter L., Canadell, P. \& Dhakal, S. Carbon reductions and offsets Report No. 6 (Global Carbon Project, 2007); available via http://go.nature.com/A8zsz3

42. Denman, K. L. \& Brasseur, G. in IPCC Climate Change 2007: The Physical Science Basis (eds Solomon, S. D. et al.) 515 (Cambridge Univ. Press, 2007)

43. Olofsson, J. \& Hickler, T. Effects of human land-use on the global carbon cycle during the last 6,000 years. Veget. Hist. Archaeobot. 17, 605-615 (2008)

44. Plattner, G. K. et al. Long-term climate commitments projected with climatecarbon cycle models. J. Clim. 21, 2721-2751 (2008)

45. Le Quéré, C. Trends in the sources and sinks of carbon dioxide. Nature Geosci. 2, 831-836 (2009)

46. Le Quéré, C. et al. The global carbon budget 1959-2011. Earth Syst. Sci. Data Discuss. 5, 1107-1157 (2012).

\section{Acknowledgements}

Thanks to Clive Hilliker for technical assistance in finalizing the production of Fig. 1. We are also grateful for insightful comments from Pierre Friedlingstein on Fig. 1 calculations.

\section{Additional information}

Supplementary information is available in the online version of the paper. Reprints and permissions information is available online at www.nature.com/reprints. Correspondence should be addressed to B.M.

\section{Competing financial interests}

The authors declare no competing financial interests. 